\title{
Utilizing Web 2.0 Tools in a Group Based Learning Environment: A Malaysian Classroom Perspective
}

\author{
Wai-Jing Kwok and Tse-Kian Neo
}

\begin{abstract}
The appropriateness of Web 2.0 tools implementation help engage students' learning by enhancing their problem solving skills. Working cooperatively is a concern for the student in order to learn in the cooperative learning environment. Therefore, this paper focuses on the use of Web 2.0 tools that can enhance the students' learning within the group-based learning context. This research had highlighted on the undergraduate students that studied in a course under environmental design, and the purpose of this class were created to require the students to work in a small team in order to develop a modelled exhibition booth for their specific brand chosen. Blog serves to be a tool in order for the students to have interaction with their peers and to form a classroom learning community within that learning environment. The intention of this research is to investigate the student's learning experience and attitude towards the use of the web-logs when students were doing their group work. A survey that consist of 5-point Likert scale were given to the students to retrieve their feedback after they had use the web-logs as the documentation for their learning processes. Research results had showed that the students enjoy using the blogs as their learning tool to show their best work. Therefore, the output of this study managed to foster the students to become techno-savvy learners and able to work together as a team in order to achieve their final goals.
\end{abstract}

Index Terms-Web 2.0 tools, group-based learning, problem solving.

\section{INTRODUCTION}

The potential usage of the Information Communication Technology (ICT) had now vastly changed the students to become more engage in their learning environment. Literature suggested that the technology tools have now increase students learning attention by having various interactivities happen within that learning environment. The learning activities have potentially engaged a more learner-centred environment [1]. Web 2.0 social media tools such as Bloggers, Twitters or Facebook are the tools that usually being widely used in the class since it is free for the public. With that, the use of web social media turns out to be a tool to lead the students towards learning engagement as well as increasing their learning achievement [2]. While cooperating with the team members, the tools were act like a bridge connection for the students to interact with their peers or team members in order to engage their interactive learning experience even more.

Learning in the team tend to increase students learning attention as they will be gradual discussion and

Manuscript received December 26, 2013; revised February 11, 2014.

Wai-Jing Kwok and Tse-Kian Neo SMILE are with the Faculty of Creative Multimedia, Multimedia University, Malaysia (e-mail: wjkwok@mmu.edu.my). communication activity happen within the learning environment [3]. It engaged the team spirit for producing a better work and therefore enhances the social interactive context which managed to help themselves to become more proactive. With the dynamic appearance on blog, it definitely made easy for the learner to voice out freely as well [4]. This study focusing on how the students work cooperatively in a team by utilizing the Web 2.0 tools available to enhance their learning into the next level. The objective of this study is to retrieve their feedback on what are their great learning experience obtain from the use of web 2.0 tools within the group-based learning context.

\section{INTERACTIVE Web 2.0 TOOLS TOWARDS EDUCATION}

Web 2.0 has been existed since the $21^{\text {st }}$ century and it is no longer something new for the people who live in the world of technology. It served as a tool for social networking, peer to peer media sharing as well as media communication usage [5]. But along the years of enhancing on the interactive experience using Web 2.0, there was a drastic growth of interest showed in the education sectors [6]. Social interaction tends to be one of the major concern for increasing students' learning attention in the education perspective [7]. The term Web 2.0 produce an interactive learning experience that can enhance the communication between the users in the sense that bring out the new ways of teaching and learning method to another level [8]. Group interaction therefore leads to the students to become more engaged and participate into their learning process. The active participation and communication initiatives hence emphasize into students' learning to become a more user control towards shaping their learning experiences [9].

\section{BLOGGING - PERSONAL DiARIES FOR LEARNING PROCESS}

Blogging tools had now shifted into a more students centred and customize ways for students to document their learning process [10]. This leads to a creation of new knowledge repository for the students to retrieve and disseminate their learning experience to others. Blogging help students to transfer their knowledge from one point to another, and at the same time; feedback or new discovery will retrieve whenever other students gives comments or suggestions. Blogging tool in learning now able to shift the original purpose from writing diaries online towards a digital application that help students to share their knowledge among themselves [11]. The practices had now shifting from individual learning towards social learning; a much network 
interconnecting and media rich kind of learning environment. This tool effectively portray to the learners for not just obtaining various information, but also able to help the students moving forward to the development of a cooperative, interactive as well as creative skills [12].

\section{STUDY AIM}

In this study, students were having an interactive class experience which consists of learning on how to create or develop a final output of exhibition booth to promote further on the specific brandings they had chosen earlier for their project. The students were in the second year (Beta) of the Advertising Design majoring from Faculty of Creative Multimedia, Multimedia University. This class consists of 81 students in total $(\mathrm{N}=81)$. The student age were ranged between 18 to 25 and already hold their foundation qualifications in design. They were entering into their selected majoring to further pursue their studies in specific for Advertising Design. The subject duration took 14 weeks and by the end of this subject, the students were required to work in a small team (a team of 2 person per group) in order to develop a modelled exhibition booth for their specific brand chosen. The blogging tools were used to trigger the interaction within the students and peers, and then to form an interactive classroom learning community within the learning environment. Fig. 1 showed the whole class description for this particular subject:

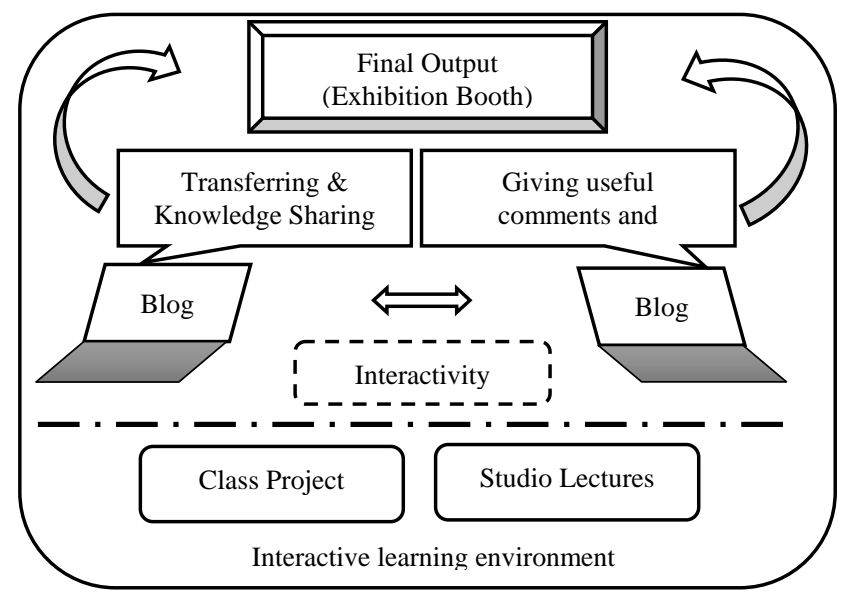

Fig. 1. Class description.

\section{THE LEARNING ACTIVITIES}

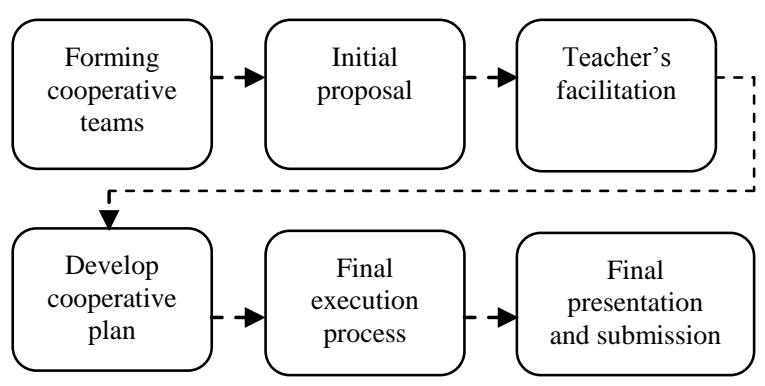

Fig. 2. The learning activities.

The overall project description in this study Fig. 2 had categorized into 6 stages, and each of the stage were required students to actively participate themselves in order to achieve their final project goal. It started off with the students were required to form in a groups of 2 . Since it was only 2 person per group, the students have to decide either one of them have to be nominated as the group leader and have to be responsible for the team in order develop their final output. Once the group had formed, they were required to come out with an initial proposal deciding on what types of local branding they should choose to be applied into the development of the exhibition booth creation. The team then have to discuss and give necessary suggestions to get the concept or idea to be firm before they even could move on for the execution.

Along the learning process, teachers were acted as the "facilitator" to give necessary assistance and suggestions for the students when they needed any help. Lectures, tutorials, or even showing creative examples were necessary given to the students in order to enhance their learning process. Consultations with the students were also needed in order to let the students have more opportunity to perform self-exploration besides the normal class hour. The students then have to start developing their cooperative plan by organizing on how they going document their learning process of their project. Blogging helps the student to organize in a better way. The students were required to create a web-log (blog) to start documenting their work such as the design layout, rough sketches, minutes of meeting regarding their discussion topics etc.

During the execution process, each of the group have to start apply their knowledge and technical skills in order to execute for the final output. According to [13], the authoring process acted as a guideline for the group and they have to apply whatever knowledge they had learnt throughout the class and apply into the final execution. Each of the group then has to rely on their team member's skills in order to develop their final output. Finally, the students were required to present their final output during the final presentation in the studio. Assessments will be given by the lecturers and they were also had to be prepared to receive suggestions and comments from the rest of the classmates. Once the presentation is done, they were required to submit their final work in softcopy format. The students were also have to complete their blogging updates and lecturers will made necessary assessment based on the blogging entries they had updated.

\section{Methodology}

In this study, a survey consisted of 5-Point Likert Scale (scale range as Strongly Disagree (1), Disagree (2), Undecided (3), Agree (4) and Strongly Agree (5)) were being conducted to retrieve the feedback on how they feel about after they had use the blogs as the documentation for their learning processes. The items used in this likert scale survey were in a total of 25. Among the total of the class participation, 71 students $(n=71)$ managed to complete the survey given. The data of this survey collected were then being entered into SPSS version 13.0 for further analysis. A descriptive analysis was performed in order to retrieve their 
feedback from the survey (See Fig. 3 and Fig. 4).

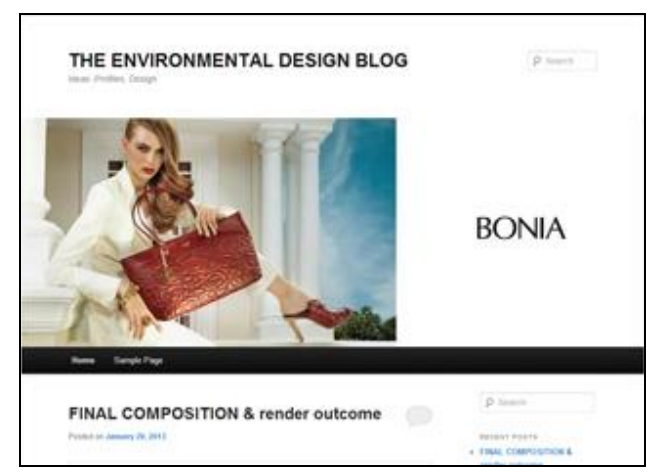

Fig. 3. Students blog $1-$ Brand (Bonia).

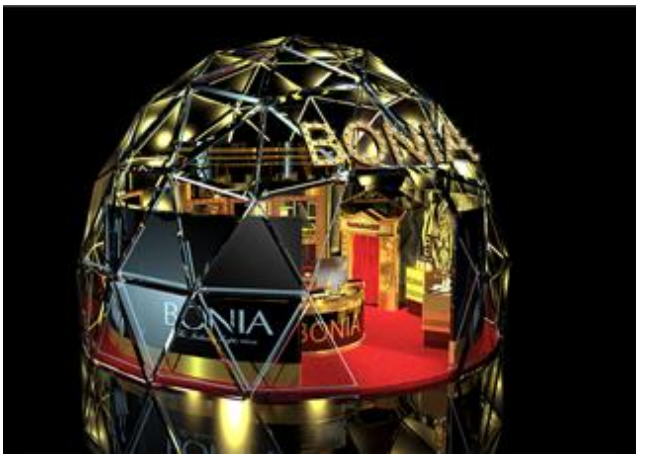

Fig. 4. Exhibition booth output (Bonia).

\section{RESULTS AND DISCUSSION}

In this study, the overall reliability or Cronbach's Alpha (Table I) obtained from the surveys were relatively high. According to [14], the reliability of data were measure through the Cronbach's Alpha which to indicate how reliable the data was. In this case the reliability results obtained from this survey were achieved at 0.958 . The reliability value usually took place in between zero to one. If the reliability values of the survey reach 0.6 and above, the results will then be proved and considered dependable [15]. Therefore, in this survey; the reliability value was obviously deemed reliable. The overall results of the survey were shown below in Table II:

TABLE I: RELIABILITY STATISTICS

\begin{tabular}{|c|c|c|}
\hline $\begin{array}{c}\text { Cronbach's } \\
\text { Alpha }\end{array}$ & $\begin{array}{c}\text { Cronbach's } \\
\text { Alpha Based on } \\
\text { Standardized } \\
\text { Items }\end{array}$ & N of Items \\
\hline .958 & .959 & 25 \\
\hline
\end{tabular}

Among all the surveys given to the class, a total of 71 students survey feedback were retrieved. Results showed the mean obtained from all the 25 items in the Likert scale survey were range from 2.99 until 4.06.

\section{A. Convenient Access to Blog}

Result in this particular survey showed that, students were actively participating into the blogging process due to easy accessibility. Students felt it was convenient for them to document their learning process using blogs. From there it helps further for the students' development and reflection towards their understanding on the subject. Findings that were discovered in this survey (Item 1, 2, 3, 5 and 13) also attained high means (M), ranging from $3.48-3.99$. Students gain the interest of actively using the blog to further enhance their learning process. Easy accessibility such as able to uploading various media files made students enjoy sharing their learnt contents to the rest of the class.

TABLE II: FREQUENCY STATISTICS OF THE WEB 2.0 SURVEY

\begin{tabular}{|c|c|c|c|c|c|}
\hline No & Survey & $\begin{array}{l}\text { Negative } \\
\text { Feedback }\end{array}$ & $\begin{array}{c}\text { Neutral } \\
\text { Feedback }\end{array}$ & $\begin{array}{l}\text { Positive } \\
\text { Feedback }\end{array}$ & $\begin{array}{c}\text { Mean } \\
(M)\end{array}$ \\
\hline & Web 2.0 & & & & \\
\hline 1 & $\begin{array}{l}\text { Blog able to document my } \\
\text { learning progress. }\end{array}$ & $\begin{array}{c}5 \\
(7.0) \\
\end{array}$ & $\begin{array}{c}11 \\
(15.5) \\
\end{array}$ & $\begin{array}{c}55 \\
(77.5) \\
\end{array}$ & 3.93 \\
\hline 2 & $\begin{array}{l}\text { Blog able to upload my } \\
\text { media files (images, video } \\
\text { etc). }\end{array}$ & $\begin{array}{c}5 \\
(7.0)\end{array}$ & $\begin{array}{c}8 \\
(11.3)\end{array}$ & $\begin{array}{c}58 \\
(81.7)\end{array}$ & 3.99 \\
\hline 3 & $\begin{array}{l}\text { Enjoy using the blogs for } \\
\text { learning. }\end{array}$ & $\begin{array}{c}12 \\
(16.9)\end{array}$ & $\begin{array}{c}22 \\
(31.0)\end{array}$ & $\begin{array}{c}37 \\
(52.1)\end{array}$ & 3.48 \\
\hline 4 & $\begin{array}{l}\text { Blog helped to write my } \\
\text { project progress }\end{array}$ & $\begin{array}{c}3 \\
(4.2) \\
\end{array}$ & $\begin{array}{c}17 \\
(23.9) \\
\end{array}$ & $\begin{array}{c}51 \\
(71.8) \\
\end{array}$ & 3.83 \\
\hline 5 & Blog was easy to use. & $\begin{array}{c}5 \\
(7.0)\end{array}$ & $\begin{array}{c}10 \\
(14.1)\end{array}$ & $\begin{array}{c}56 \\
(78.8)\end{array}$ & 3.92 \\
\hline 6 & $\begin{array}{l}\text { Able to learn more about } \\
\text { the course using blogs. }\end{array}$ & $\begin{array}{c}8 \\
(9.3)\end{array}$ & $\begin{array}{c}28 \\
(39.4)\end{array}$ & $\begin{array}{c}35 \\
(49.3)\end{array}$ & 3.49 \\
\hline 7 & $\begin{array}{l}\text { Blog helped reflect my } \\
\text { learning by writing } \\
\text { entries. }\end{array}$ & $\begin{array}{c}5 \\
(7.0)\end{array}$ & $\begin{array}{c}21 \\
(29.6)\end{array}$ & $\begin{array}{c}45 \\
(63.4)\end{array}$ & 3.70 \\
\hline 8 & $\begin{array}{l}\text { Blog enhanced my } \\
\text { learning. }\end{array}$ & $\begin{array}{c}8 \\
(9.9)\end{array}$ & $\begin{array}{c}20 \\
(28.2)\end{array}$ & $\begin{array}{c}44 \\
(55.9)\end{array}$ & 3.63 \\
\hline 9 & $\begin{array}{l}\text { Reading my own entries } \\
\text { able to reflect on my work. }\end{array}$ & $\begin{array}{c}1 \\
(1.4)\end{array}$ & $\begin{array}{c}16 \\
(22.5)\end{array}$ & $\begin{array}{c}54 \\
(76.0)\end{array}$ & 3.97 \\
\hline 10 & $\begin{array}{l}\text { Reading other blogs able } \\
\text { to increase my } \\
\text { understanding of the } \\
\text { course. }\end{array}$ & $\begin{array}{c}3 \\
(4.2)\end{array}$ & $\begin{array}{c}11 \\
(15.5)\end{array}$ & $\begin{array}{c}57 \\
(80.3)\end{array}$ & 4.01 \\
\hline 11 & $\begin{array}{l}\text { Able to write comments on } \\
\text { other people's blog. }\end{array}$ & $\begin{array}{c}18 \\
(25.4)\end{array}$ & $\begin{array}{c}34 \\
(47.9)\end{array}$ & $\begin{array}{c}19 \\
(26.7)\end{array}$ & 2.99 \\
\hline 12 & $\begin{array}{l}\text { Able to receive comments } \\
\text { on my blogs. }\end{array}$ & $\begin{array}{c}9 \\
(12.7) \\
\end{array}$ & $\begin{array}{c}23 \\
(32.4)\end{array}$ & $\begin{array}{c}39 \\
(54.9) \\
\end{array}$ & 3.59 \\
\hline 13 & $\begin{array}{l}\text { Blog comments made me } \\
\text { learn more about my work. }\end{array}$ & $\begin{array}{c}7 \\
(9.8)\end{array}$ & $\begin{array}{c}27 \\
(38.0)\end{array}$ & $\begin{array}{c}37 \\
(52.1)\end{array}$ & 3.49 \\
\hline 14 & $\begin{array}{l}\text { Blog comments managed } \\
\text { to enhance my work. }\end{array}$ & $\begin{array}{c}4 \\
(5.6)\end{array}$ & $\begin{array}{c}29 \\
(40.8)\end{array}$ & $\begin{array}{c}37 \\
(53.6)\end{array}$ & 3.56 \\
\hline 15 & $\begin{array}{l}\text { Able to comment on other } \\
\text { people's blogs. }\end{array}$ & $\begin{array}{c}11 \\
(15.5)\end{array}$ & $\begin{array}{c}23 \\
(32.4)\end{array}$ & $\begin{array}{c}37 \\
(52.2)\end{array}$ & 3.41 \\
\hline 16 & $\begin{array}{l}\text { Blogs able to } \\
\text { communicate my progress } \\
\text { to my group mates. }\end{array}$ & $\begin{array}{c}14 \\
(19.7)\end{array}$ & $\begin{array}{c}22 \\
(31.0)\end{array}$ & $\begin{array}{c}35 \\
(49.3)\end{array}$ & 3.37 \\
\hline 17 & $\begin{array}{l}\text { Able to comment on my } \\
\text { group mates' work through } \\
\text { blogs. }\end{array}$ & $\begin{array}{c}7 \\
(9.8)\end{array}$ & $\begin{array}{c}23 \\
(32.4)\end{array}$ & $\begin{array}{c}41 \\
(57.8)\end{array}$ & 3.52 \\
\hline 18 & $\begin{array}{l}\text { Able to cooperate together } \\
\text { more efficiently through } \\
\text { the use of blog }\end{array}$ & $\begin{array}{c}12 \\
(16.9)\end{array}$ & $\begin{array}{c}24 \\
(33.8)\end{array}$ & $\begin{array}{c}35 \\
(49.3)\end{array}$ & 3.38 \\
\hline 19 & $\begin{array}{l}\text { Blogs helped enhanced } \\
\text { group skills. }\end{array}$ & $\begin{array}{c}16 \\
(22.5) \\
\end{array}$ & $\begin{array}{c}25 \\
(35.2) \\
\end{array}$ & $\begin{array}{c}30 \\
(42.30 \\
\end{array}$ & 3.27 \\
\hline 20 & $\begin{array}{l}\text { Using blog managed to } \\
\text { solve problems as a team. }\end{array}$ & $\begin{array}{c}13 \\
(18.3)\end{array}$ & $\begin{array}{c}27 \\
(38.0)\end{array}$ & $\begin{array}{c}31 \\
(43.7)\end{array}$ & 3.34 \\
\hline 21 & $\begin{array}{l}\text { Able to learn even more by } \\
\text { reading other blogs. }\end{array}$ & $\begin{array}{c}5 \\
(7.0)\end{array}$ & $\begin{array}{c}11 \\
(15.5)\end{array}$ & $\begin{array}{c}55 \\
(77.4)\end{array}$ & 3.86 \\
\hline 22 & $\begin{array}{l}\text { Reading other blogs } \\
\text { allowed me to show my } \\
\text { best work. }\end{array}$ & $\begin{array}{c}3 \\
(4.2)\end{array}$ & $\begin{array}{c}16 \\
(22.5)\end{array}$ & $\begin{array}{c}52 \\
(73.2)\end{array}$ & 3.89 \\
\hline 23 & $\begin{array}{l}\text { Able to generate better } \\
\text { idea by reading others } \\
\text { blog. }\end{array}$ & $\begin{array}{c}5 \\
(7.0)\end{array}$ & $\begin{array}{c}9 \\
(12.7)\end{array}$ & $\begin{array}{c}57 \\
(80.3)\end{array}$ & 3.90 \\
\hline 24 & $\begin{array}{l}\text { Blog able to compare the } \\
\text { quality of the work with } \\
\text { others. }\end{array}$ & $\begin{array}{c}3 \\
(4.2)\end{array}$ & $\begin{array}{c}8 \\
(11.3)\end{array}$ & $\begin{array}{c}60 \\
(84.5)\end{array}$ & 4.06 \\
\hline 25 & $\begin{array}{l}\text { By looking at other blogs } \\
\text { manage to solve problems } \\
\text { by in the course }\end{array}$ & $\begin{array}{c}2 \\
(2.8)\end{array}$ & $\begin{array}{c}20 \\
(28.2)\end{array}$ & $\begin{array}{c}49 \\
(69.0)\end{array}$ & 3.87 \\
\hline
\end{tabular}




\section{B. Students' Engagement towards Blogging}

In this survey, results indicated that students were engaged by frequently using the blog on their learning. Item $4,12,18$, 22 and 23 indicated the engagement elements towards the blogs were the means (M) obtained were ranged from 3.38 to 3.90. Students were able to write their project progress easily by using blog. Besides, the students were also felt comfortable to accept comments from the others. Students felt engaged when there was a team spirit of working together as a group while utilizing the blog as their supporting tools in the learning process. They even feel engaged when referring others blogs as reference to enhance further on their own work.

\section{Able to Comment}

By using the blogs in this learning environment, students were able to learn more about the project. Result showed in this particular area (Item 6, 11, 15, 16 and 17) indicated the means (M) were ranged from 2.99 to 3.49. Students were enjoyed writing comments in the blogs because it able to tie a closer connection of further communicating their learning progress to their group mates. However, there was also a discovery found out that students were actually afraid of writing comments to other student's blog. This may because that this was their first experience of using blogs in their learning. Students don't feel comfortable to give any comments as they felt it was difficult and time consuming to think of what to write on. But in overall, students were able to produce useful comments by posting and share their experience inside their blog page.

\section{Generate Problem Solving Skills through Group Work}

It was vital for the students to be able to value the importance of problem solving skills in their learning environment. Results in this study showed that students were able to reflect their learning effectively by gradually writing on their blog entries (Item 7, 9, 20, 24 and 25). The items means $(\mathrm{M})$ obtained from this survey were achieved at the very high mean ranged 3.34 to 4.06. Through the use of blog, students were able to compare the quality of their own work with others as to identify their weaknesses and further improving their problem solving skills.

By gradually reading others blog, student were able to solve their work problem which they couldn't never discover on their own. Reading on their own blog entries were also able to make themselves "self-reflect" towards their own work creation. Therefore it able to generate a higher problem solving skills embedded in each student to further enhance their work.

\section{E. Enhancing Students' Learning Experience}

The results showed that students' understanding towards the course was significantly increased due to the gradual readings from other students' blog. Findings that were discovered in this survey (Item 8, 10, 14, 19 and 21) attained at high means (M), ranging from 3.27 to 4.01 . The gradual process of reading and writing using blogs help students enhanced further their learning experience in this course. They felt that blog were helpful in order to enhance their group skills. Besides that, by receiving useful comments from others able to help the students to further enhance their work even more.

\section{CONCLUDING REMARK}

Studies from various literatures showed that students were engaged in group-based learning with Web 2.0 tools as enabler did brought challenges and frustrations. But the findings from this study managed to foster the students to become techno-savvy learners and able to work together as team in order to achieve their final goals. Students were gradually improving themselves with the use of technology by retrieving various sources from the internet to learn. Although there were still some students who felt uncomfortable of using blog, but this doesn't lead to the failure of utilizing blog in the learning environment. Instead, it made the students felt that it was a good opportunity to take this challenge in order for them to further enhance their blogging skills.

Therefore, their learning engagement had increase and imposes the learning interest to become more proactive in their work. Besides that, it also enhances the students' interaction communication skills through the use of the Web 2.0 tools. Therefore it leads the students to another level of enhancing their creative learning experience.

\section{ACKNOWLEDGMENT}

Great appreciation goes to my supervisor, Assoc. Prof. Dr. Neo Tse Kian for his endless guidance and support throughout the development of this conference paper. I would also like to thank all the people who have contributed their assistance and helped me to their own special ways. Without their greatest support, I believed this paper would not be able to achieve.

\section{REFERENCES}

[1] L. Revere and J. V. Kovach, "Online technologies for online learning: A meaningful synthesis for educators," The Quarterly Review of Distance Education, vol. 12, no. 2, pp. 113-124, 2011.

[2] B. K. Welch and J. B. White, "Twittering to increase student engagement in the university classroom," Knowledge Management and E-Learning: An International Journal, vol. 4, no. 3, pp. 325-345, 2012.

[3] P. G. Zimbardo, L. D. Butler, and V. A. Wolfe, "Cooperative college examinations: More gain, less pain when students share information and grades," The Journal of Experimental Education, vol. 71, pp. 101-125, 2003.

[4] L. B. Andreason, "Weblogs as forums for discussion - an alternative to the computer conference as a standard in online learning?" in Media and ICT-learning potentials, M. Buhl, B. Meyer, and B. S. Holm, (eds.), Copenhagen: Danish University of Education Press, 2006, pp. 71-88.

[5] T. O'Reilly. (2005). What is Web 2.0: Design Patterns and Business Models for the Next Generation of Software. [Online]. Available: http://www.oreillynet.com/pub/a/oreilly/tim/news/2005/09/30/what-is -web-20.html

[6] B. Alexander. (2006). Web 2.0: A new wave of innovation for teaching and learning? EDUCAUSE Review. [Online]. 41(2). pp. 32-44. Available: http://www.educase.edu.ir/library/pdf/ERM0621.pdf

[7] D. Boyd, "The significance of social software," in Blog Talks Reloaded: Social Software Research and Cases Norderstedt, T. N. Burg and J. Schmidt, (Eds.), Germany: Books on Demand, 2007, pp. 15-30.

[8] J. W. P. Goh, C. J. Quek, and O. K. Lee, “An investigation of students' perceptions of learning benefits of weblogs in an East Asian context: A Rasch analysis," Educational Technology and Society, vol. 13, no. 2, pp. 90-101, 2010.

[9] S. D. Freitas and G. Conole, "Learners experiences: How pervasive and intergrative tools influence expectations of study," in Rethinking Learning for a Digital Age: How Learners are Shaping Their Own 
Experiences, R. Sharpe, H. Beetham, and S. De Fretais (Eds.), London: Routledge, 2010, pp. 15-30.

[10] V. Harada, "From instruction to construction: Learning in the information age," in Educational Media and Technology Yearbook 2003, M. Orey and R. Branch (Eds.), Westport, CT: Libraries Unlimited, 2003, pp. 40-48.

[11] G. Conole, "Stepping over the edge: The implications of new technologies for education," in Web 2.0-Based e-Learning: Applying Social Informatics for Tertiary Teaching, M. J. W. Lee and C. Loughlin (Eds.), Hershey: IGI Global, 2010.

[12] C. Redecker, K. A. Mutka, M. Bacigalupo, A. Ferrari, and Y. Punie. (2009). Learning 2.0: The impact of Web 2.0 innovations in education and training in Europe. Seville: Institute for prospective Technological Studies. [Online]. Available: http://ipts.jrc.ec.europa.eu/publications/pub.cfm?id=2899

[13] M. Neo, T. K. Neo, and M. E. Rafi, "Designing interactive multimedia curricula to enhance teaching and learning in the Malaysian classroom - From teacher-led to student-centred experiences," The International Journal of Instructional Media, vol. 34, no. 1, 2004.

[14] R. F. DeVellis, Scare Development: Theory and Applications, $2^{\text {nd }}$ Eds. Newbury Park, CA: Sage Publications, 2003.

[15] N. K. Malhotra and D. F. Birks, Marketing Research-an Applied Approach, $3^{\text {rd }}$ Edition, Pearson Education Limited, 2007.

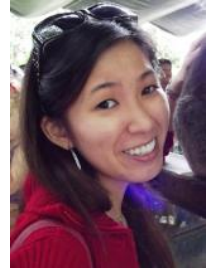

Wai-Jing Kwok is a Ph.D. postgraduate student, a member of student-centred Multimedia Learning Environment (SMILE), in the Faculty of Creative Multimedia, Multimedia University (MMU). She obtained her first degree in bachelors of multimedia, major in media innovation, in Multimedia University (MMU) Cyberjaya, Malaysia in year 2006. She also managed to earn her master degree in master of knowledge management at the same institution in year 2009. She managed to perform her 3 months internship at PKM Technologies Sdn. Bhd in year 2005. Once graduated from her degree, she continued to pursue her master degree back in the same university and earned a job opportunity within the campus to become a research officer for 2 years and a research scholar for a year. She also being active as a university researcher in MMU and currently she is a lecturer in Multimedia University (MMU), Cyberjaya. Along the years of research, she managed to publish a few journals and conference publications including International Journal of Learning Volume (IJL) as well as Australasian Society for Computers in Learning in Tertiary Education (Ascilite). Her research interest focuses on the Cooperative learning aspects and multimedia education technology perspective. Ms. Kwok is also being active as a secretariat member in the International Conference on Informatics and Creative Multimedia (ICICM'13). Lately, her research team managed to won a silver medal in the ICICM'13 research exhibition with the title of "Developing a Student-Centred Learning Platform: The MILE Project". 